mansasa

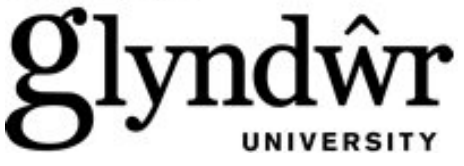

Glyndŵr University

Glyndŵr University Research Online

Professional and Vocational Education Research

Unit

Education

$2-1-2011$

\title{
Undertaking an institutional 'stock-take' of SoTL: New Zealand university case studies
}

Neil Haigh

Peter Gossman

Glyndwr University, p.gossman@glyndwr.ac.uk

Xiaomin Jiao

Follow this and additional works at: http://epubs.glyndwr.ac.uk/cprs

Part of the Educational Assessment, Evaluation, and Research Commons, Higher Education $\underline{\text { Administration Commons, International and Comparative Education Commons, Other Education }}$ Commons, and the Teacher Education and Professional Development Commons

Copyright (C) 2011 Routledge Taylor and Francis. This is the authors final version of the work before publication. This article was published in Higher Education Research \& Development Journal by Routledge Taylor and Francis in 2011. The published article is available online at http://dx.doi.org/10.1080/07294360.2011.536969

\section{Recommended Citation}

Haigh, N., Gossman, P., and Jiao, X. (2011) “Undertaking an institutional 'stock-take' of SoTL: New Zealand university case studies", Higher Education Research \& Development, 30(1), $9-23$

This Article is brought to you for free and open access by the Education at Glyndŵr University Research Online. It has been accepted for inclusion in Professional and Vocational Education Research Unit by an authorized administrator of Glyndŵr University Research Online. For more information, please contact d.jepson@glyndwr.ac.uk. 


\section{Undertaking an institutional 'stock-take' of SoTL: New Zealand university case studies}

Neil Haigh*, Peter Gossman** and Xiaomin Jiao*

*AUT University, Auckland, New Zealand

** Glyndŵr University, Wrexham, UK

Corresponding author: Neil Haigh

Research and Scholarship Development, Centre for Educational and Professional Development, AUT University, Duthie Whyte Building, 102 Mayoral Drive, Private Bag 92006, Auckland 1020, New Zealand. Email: neil.haigh@aut.ac.nz 


\title{
Undertaking an institutional 'stock-take' of SoTL: New Zealand university case studies
}

\begin{abstract}
A working group was established at AUT University in 2005 with a brief to identify initiatives that might be taken to promote and support staff engagement in the scholarship of teaching and learning (SoTL). The working group recognized that a 'stock-taking' exercise would need to be undertaken before appropriate initiatives could be identified, trialled and evaluated. In this article, ${ }^{1}$ the methodology and specific methods used for the stock-take, which included bench-marking with other New Zealand universities, are outlined and key findings are presented and discussed. These findings provide a helpful snapshot of the presence of SoTL within New Zealand universities and within the everyday lives of New Zealand university teachers. They highlight the complexity of those lives and tertiary institution environments which can make it challenging for teachers to become more scholarly and to engage in SoTL. They also point to ways in which those environments may be made more conducive to the realization of these goals.
\end{abstract}

Keywords: Scholarship of teaching and learning (SoTL); Engagement; Case study; Influence; Evaluation

\section{Introduction}

In 2005, one of the authors, who has an academic development role within the AUT University Centre for Educational and Professional Development, established a working group to assist him with planning and implementation of initiatives intended to encourage and support engagement of AUT University staff in the scholarship of teaching and learning (SoTL). The working group members quickly recognized that they lacked comprehensive and accurate information about the current status of SoTL within the university, and which future planning should be founded on. Therefore, it was decided that a 'stock-taking' exercise should be undertaken to obtain this information.

As a component of the stock-take, it was decided to bench-mark AUT University with other New Zealand Universities and two universities agreed to participate with the expectation of reciprocal benefits. ${ }^{2} \mathrm{We}$ took into account of comparable initiatives internationally when planning the project. Of particular value were 'Mapping Progress' surveys undertaken by a number of U.S. universities which were participants in a 'Campus Program' of the Carnegie Foundation for the Scholarship of Teaching and Learning (CASTL). ${ }^{3}$ The survey reports provided exemplars of possible 'indices of progress'. We also identified other surveys of teachers' views about SoTL, including their perceptions of incentives and barriers to engagement in SoTL (e.g., Lynch et al., 2002; Wankat et al., 2002; Sample, 2004; Oakey et al., 2004; U.K. Centre for Education in the Built Environment, 2005). While anticipating that findings from these investigations could be generalised to New Zealand universities, we considered that the distinctive features of national environments, institutions, faculty/departments, disciplines, subjects and professions need to be taken into

\footnotetext{
${ }^{1}$ For a copy of a comprehensive report on the project (Gossman et al., 2009), which was funded by the New Zealand Ministry of Education, contact Neil Haigh.

2 Massey University, University of Canterbury. Some additional data was gathered from other New Zealand and Australian Universities

${ }^{3}$ For an example of a 'Mapping Progress' report see www.indiana.edu/ sotl/download/mpr_0202.doc
} 
account. When this project was initiated, there were no comparable surveys for New Zealand universities. However, we were aware that SoTL was already given a strong emphasis in academic staff development programmes within New Zealand universities, and a preliminary review of research outputs from New Zealand universities confirmed that a significant number of teachers were active scholars of teaching and learning.

A critical consideration to address at the outset of the project was the meaning of the term scholarship of teaching and learning. We were aware of variations in meanings which evoke continuing commentary as well as on-going dialogue about distinctions and/or relationships between SoTL and pedagogic research, and about the notion of scholarship itself (e.g., Kreber, 2002a, 2005, 2007; Nicholls, 2005; Boshier \& Huang, 2008; Gurung, et al., 2008; Prosser, 2008; Hutchings \& Huber, 2008; Boshier, 2009). Notwithstanding variations in meanings, common to most is the notion that teachers engage in some form of systematic inquiry into, and critical reflection on, aspects of students' learning and/or teaching with the intention of improving learning (Kreber (2003). Such inquiries and reflections also embody features that give them the status of scholarship: they are made public, subjected to critical evaluation, and disseminated for use by other members of one's scholarly community (Shulman, 1998). However, while there is a concern for dissemination of insights/findings, the interests of other educators and the construction and evaluation of general theory are not usually considered foreground purposes of SoTL (Hutching \& Huber, 2008). The primary, if not exclusive, focus of the scholar of teaching and learning is their own students' learning and their own teaching practices.

\section{Framework, data, methodology, and methods}

\section{Framework}

The framework for the stock-take was based on five key objectives:

1. identify the features of institutional policies, provisions and programmes that explicitly/implicitly endorse, encourage and support SoTL,

2. describe the status and features of SoTL activities and publications,

3. compare the status and features of SoTL with respect to different faculties/disciplines,

4. identify experiences and views of staff who are, and are not, engaged in SoTL, and

5. identify criteria that can be used to evaluate the impact of SoTL initiatives on teaching and student learning.

\footnotetext{
${ }^{4}$ We provide a comprehensive discussion of the concept in the full report on the project (Gossman et al., 2009).
} 
A wide array of data was gathered in relation to these objectives.

\section{Objective one:}

Statements in national and institutional policies, plans and reports that denote awareness of SoTL and a commitment to encouraging, supporting and rewarding staff engagement in SoTL. The documents included:

a. National: New Zealand Ministry of Education - The Tertiary Education Strategy 2007 - 2015; Statement of Tertiary Education Priorities 2005 - 2007.

b. Institutional: Charters, strategic plans, annual reports, investment plans, teaching and learning policy/plans, teaching excellence award criteria.

Evidence of provisions, programmes and actions intended to encourage, support and reward engagement in SoTL. Examples of related data were purpose statements for the work of staff in academic development centres, position descriptions specifying SoTL-related responsibilities, funding for SoTL projects and dissemination, attention to SoTL in programmes (e.g., postgraduate diploma of tertiary teaching), guidance for staff undertaking SoTL project, and resources on SoTL.

\section{Objective two:}

Records of SoTL publications in the three case study institutions' annual research output reports. While these forms of publications do not encompass all of the possible variants for publicized work that is representative of SoTL, most have the status of peer-reviewed products. Publication title was the basis for selection and publication type was also recorded. Time precluded our reading all publication to validate selections and to categorize other features of the scholarship.

\section{Objectives three and four:}

The data included:

- the number of SoTL publications produced by each Faculty (at AUT University)

- $\quad$ perceived degree of engagement in SoTL (scale based on the work of Trigwell et al.,2000).

\begin{tabular}{cl}
$\begin{array}{c}\text { Degree of } \\
\text { SoTL } \\
\text { Engagement }\end{array}$ & \multicolumn{1}{c}{ Description of SoTL position } \\
1 & $\begin{array}{l}\text { My teaching is informed by the teaching that I have experienced as a } \\
\text { learner and by my own practical experiences. }\end{array}$ \\
2 & $\begin{array}{l}\text { I read literature on teaching and learning in order to build my own } \\
\text { knowledge of teaching and learning. }\end{array}$ \\
& $\begin{array}{l}\text { I read literature on teaching and learning with the intention of applying } \\
\text { ideas to improve my own teaching practice. I have been able to achieve } \\
\text { this on more than one occasion. }\end{array}$ \\
& $\begin{array}{l}\text { I read education literature with the intention of applying the ideas to } \\
\text { improve my teaching practice and my students' learning. My reading } \\
\text { informs my research into improving my teaching. }\end{array}$ \\
& $\begin{array}{l}\text { I read both general education literature and literature about teaching } \\
\text { and learning in my discipline(s). My intention has been to apply ideas } \\
\text { from these two sources in order to improve my own teaching practice } \\
\text { and my students' learning. My reading informs my research into }\end{array}$
\end{tabular}


improving my teaching.

By reading literature on teaching and learning I have informed and changed my teaching practice in order to improve student learning. My reading has informed research into my teaching and my students' learning. My research has been made public in some way (e.g., seminar, paper, conference.).

- anticipated change in engagement in SoTL (in 2 years, in 5 years),

- explanations for anticipated change,

- perceptions of existing and possible incentives and disincentives for changed engagement, and

- perceived advantages/disadvantages of engaging in SoTL.

For staff at AUT University, the data also included background information on years of teaching experience, level of academic position, highest academic qualification, teaching discipline (soft/applied, soft/pure, hard/applied, hard/pure), teaching conceptions and their perceptions of factors promoting and hindering involvement in SoTL.

\section{Objective five:}

Views about appropriate impact indices sourced from the literature review, together with our reflected-on decisions about appropriate criteria for this stock-take.

\section{Methodology and methods}

The methodology was multiple case studies incorporating descriptive survey and correlational methods. The data gathering methods included document content analysis (objectives one and two) and a questionnaire, semi-structured interviews, focus groups and a forum dialogue (objectives three and four). The content analysis involved screening of document text for SoTL-related phrases using Nvivo software and direct reading of selected documents. Some data was gathered from the three universities; some was confined to AUT University. The questionnaire was administered to all AUT University academic staff and achieved a $12.4 \%$ response rate. While the response rate to the questionnaire was lower than desirable and precluded planned correlational statistics analyses, the data obtained from the structured interviews and focus groups extended the questionnaire data, and enabled triangulation. Structured interviews were held with 9 randomly selected AUT University staff and focus groups held at the three universities involved a further 31 staff.

\section{Case study findings and implications}

\section{The rhetoric of SoTL}

The analysis of institutional documents confirmed that the three case study institutions explicitly endorsed scholarship/research-informed learning and teaching. As illustrated by the following sample of statements, references varied in level of generality and in usage of the terms scholarship and research. 
Figure 1: Scholarship/SoTL in institutional documents (AUT University, Massey University and Canterbury University)

AUT University Charter 2005

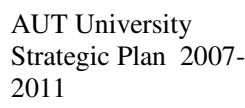

AUT University Strategic Plan 20072011

AUT University Research Development Plan (2007-2011)

AUT University Investment Plan 20082010

AUT Distinguished Teaching Award Criteria

Massey University: Defining the Road to 2020 (Strategy

Document)

Massey University Teaching Excellence Criteria

University of Canterbury Teaching and Learning Principles (2001)

University of Canterbury Charter 2003 - 2010

University of Canterbury Teaching

Award Criteria
... relevant and up to date scholarship provides the context for all teaching and learning, ...

AUT will conduct excellent research, advancing knowledge and practice in its areas of expertise and supporting its higher education programmes.

Our research will reflect Boyer's notion of scholarship and will cover the spectrum from embracing discoveries and innovations for their own sake to supporting our curriculum ...

At the core of AUT University's Research Development Plan is the concept of scholarship as teaching and learning, engagement, integration and discovery.... Within this philosophical tradition, research , education and the development of activities of tertiary institutions are informed by scholarship ...

... the philosophy of scholarship which underpins AUT University's distinctive approach to researchled education

Establishing a nexus between teaching and research that enhances students learning, including through engagement in the scholarship of teaching and learning

engage in scholarly activities and innovations that are intended to enhance learning and teaching

Our teaching programme will be informed by research

Massey wants it's teaching to be defined by learner focused research-informed learning...

The nominee shows on-going commitment to his/her own teaching and has been proactive in contributing to the development of effective teaching practice and/or the development of colleagues $\ldots$ and teaching methods and ideas are shared with colleagues either internally or externally, with evidence of positive impact on their practice.

University teachers are active in scholarship through their involvement in research, their awareness of contemporary development in their disciplines and their desire to support and encourage students in academic endeavours. The engagement of teachers within a disciplinary context is the basis for maintaining practical linkages between teaching, learning and research.

The University of Canterbury is an institution in which scholarship is valued and where teaching and learning are strongly linked to research.

acknowledged leadership in the teaching of a discipline and research and development in teaching and learning,

When current and earlier versions of such institutional documents were compared, increased references to scholarship in conjunction with teaching and learning were apparent. This may reflect regard for Government-determined expectations in relation to SoTL, as well as the current focus of all universities on the teaching-research nexus and its manifestation in research-led/informed teaching. i.e.

\section{The Tertiary Education Priorities (2005-2007) document stated that}

Excellence in research underpins effective teaching, generates knowledge and innovation, and helps drive economic goals.

As part of providing for a successful learning experience, it is important that tertiary teachers are up to date with developments in their field and this includes knowledge of research. There should be a close relationship between research and teaching. 
In the Tertiary Education Strategy $(2007$ - 2012) the first reference occurs, in such a document, to scholarship in relation to teaching, i.e.

The scholarship of teaching, and links between research and teaching more generally, must be strengthened and the government will support this, particularly through the distinctive contributions of universities.

(Ministry of Education, 2007, p. 25)

We note that members of the New Zealand branch of HERDSA made a submission during the consultation round on the Tertiary Education Strategy (TES) that advocated Government-level endorsement and support for SoTL. viz

We strongly support the expectation that the tertiary education sector continue to deliver a broad and balanced portfolio of basic, strategic and applied research and are particularly pleased to see that the this portfolio includes the scholarship of teaching (and learning) and that strengthening links between research and teaching is also proposed.... We contend that the TES should emphasize strengthening them because they are fundamental to building teaching capability and improving learning outcomes. (Haigh \& Stein, 2006)

Increased references to SoTL may also be an outcome of the on-going endeavours of academic development staff to advocate for and support scholarly teaching and SoTL.

While we acknowledge some scepticism about the impact that rhetoric can have on the everyday realities of practice, undeniably it legitimates particular practices and can provide invaluable leverage when change is promoted. We believe that academic developers and many of their teaching colleagues would appreciate a clearer elaborated institutional stance on the place of SoTL in academic work. At the same time, it is likely that academic developers will need to play a key role in helping their institutions clarify that stance and articulate it. They would also wish to see aligned statements in relevant policy areas, including appointment, promotion, study leave, and teaching awards. There are precedents for universities attempting to make their position clear and to have a set of aligned policies for the guidance of staff. However, a potential obstacle may be the difficulty of readily operationalizing the SoTL construct. Boshier (2009) attributes the latter to what he terms the 'hard sell' of SoTL and provides examples of the difficulties that may be encountered.

\section{The reality of SoTL: Actions speak louder than words}

The data gathered confirms that much SoTL-related activity is occurring, and other sources of data suggest that this is applicable for all New Zealand universities. Activities mainly originate from, and represent part of the work of, the central teaching development services within each university. There is considerable variation across the universities in the form that these 'enablers' take. While informal sharing of related information occurs when university academic developers meet, to date there has been no systematic attempt to collate and review those activities across the New Zealand university sector as a whole. A more extensive investigation and critique would be a productive sequel to this project. 
SOTL Publications: Confirmation that SoTL has a significant presence within New Zealand universities is evident in SoTL publications. While the data indicated quite variable publication patterns between the three universities during the period 2000 to 2005 and the proportion of SoTL publications to research publications overall is relatively low for this period (3.6\%), we identified 1281 contributions to the knowledge base for learning and teaching in New Zealand universities. For AUT University, which is a relatively new university (established 2000), SoTL publications represented a higher proportion of overall 'outputs' during this period (9\%) but this is now declining as disciplinary research is strongly emphasized $(2000=13 \% ; 2005=$ $3.1 \%$ ). These publications represent a significant contribution to the knowledge base on tertiary learning and teaching and the likelihood that this knowledge has immediate relevance to a New Zealand context is an important consideration.

Engagement in SoTL: The data gathered provides helpful insights into the current place of SoTL in the lives of a sample of New Zealand university teachers, their aspirations in relation to engagement in SoTL and a detailed account of factors that they perceived as likely to promote, support and reward that engagement.

For the 124 AUT University teachers who completed the degree of engagement in SoTL scale, at least two thirds quite frequently read literature about teaching in their discipline and 55\% were often responsive to that literature in terms of their own teaching practices. Two thirds also indicated that they engaged in investigations within their own classrooms, often in response to reading literature. One quarter regularly communicated with their colleagues about their investigations, with a little fewer (20\%) also communicating through a peer review process. The specific nature of investigations and communications was not explored. The data suggests that the respondents may not have been representative of the population of academic staff as a whole, when the data on published SoTL products is taken into account. That is, teachers who had a scholarly disposition to their teaching may have been more likely to respond.

With implications for academic development in mind, we note that Gayle and Randall (2007) have proposed a three stage model of Faculty Development for SoTL that acknowledges the 'in-between' and 'on the way' status that is possible as teachers move through stages of engagement. The stages, for which they offer elaborated descriptions, involve learning about one's teaching, growth in scholarly teaching and growth in SoTL. They emphasize that teachers can demonstrate attributes associated with more than one stage concurrently and that their movement through these stages is contingent on teachers" "ability to move beyond the discipline-specific strategies and tactics usually employed ... confidence in their capability to explore and implement new ideas, and the ... commitment to bringing ... theoretical knowledge and research skills to bear upon her or his teaching and student learning" (p. 2). Gayle and Randall gathered data from 167 faculty members that validate aspects of this model. There are other versions of this stage model (e.g., Kreber, 2002b) and adaptations of the Dreyfus and Dreyfus (1986) five stage conceptualization of the journey from novice to expert offer a further framework for describing the developmental status of teachers in relation to SoTL and associated development agenda implications (Smith, 2001; Richlin \& Cox, 2004; Haigh, 2006; Gossman, 2008;). 
There was a trend towards increasing involvement in SoTL as years of teaching experience increased and advancement in academic position occurred. This may reflect a priority accorded disciplinary research or their own postgraduate research by early career academics, although engaging in SoTL may be a manageable entry into research for some academics. The latter was apparent at AUT University where the change to university status in 2000 brought a new expectation that all academic staff become 'research active'. Leuddeke (2003) noted a trend of greater involvement in teaching development activities, which may reflect a disposition towards scholarly teaching, in early and later career academics.

Nearly two thirds of the respondents were from 'soft' and/or 'applied', rather than 'hard' and 'pure' disciplines (Becher, 1994). The significance of disciplinary context is emphasized in some SoTL definitions:

The scholarship of teaching involves studying, reflecting on, and communicating about teaching and learning, especially within the context of one's discipline.

(Healey, 2003, p. 20)

Healey (2000) has argued that "for most academics, developing the scholarship of teaching will only bring about change in their priorities if it is embedded in disciplines and departments" (pp.172-173). This view is founded on evidence that they are most likely to allocate their primary allegiance to their subject/profession, rather than to the institution and to perceive significant differences in the nature of the academic/scholarly activities that they engage in, when contrasted to those of colleagues in other disciplines. A by-product of this stance is the increasing number of discipline-specific higher education journals that we noted SoTL-active staff publish in.

The distribution of respondents in relation to discipline may also confirm the view that discipline-related epistemological differences as well as lack of familiarity with social science/education research can be barriers to engagement in SoTL for many academics. For example, Wankat et al. (2002) identified differences between engineering research and educational research that they considered "pose significant challenges to engineering faculty intending to engage in the latter" (p. 5). They observe that, in contrast with engineering research, educational research deals with phenomena that are usually more difficult to define precisely and often must be inferred as they cannot be observed. As a result, it is more difficult to develop precise "metrics", instruments and procedures for directly measuring whatever is to be improved.

The only way to "prove" anything in education is to run many studies on large populations and point to the same broad results. This is not the kind of reasoning engineering professors are accustomed to employing in their research, however, and most are sceptical of it. A large part of the challenge of legitimizing the scholarship of teaching in engineering education involves overcoming this scepticism. (p. 6)

Other factors that they considered to be impediments to acceptance of SoTL in engineering education included lower importance accorded teaching quality and engagement in SoTL in career progression decisions, limited response to literature on teaching and learning, the negative impact of perceptions that some academics who engage in educational research are not, themselves good teachers, weak financial support and "different vocabularies, priorities and conceptions of research". Similar 
findings have been noted for other disciplines (e.g., Coppola \& Jacobs, 2002; De Welde \& Seymour, 2008).

While some of our teachers expressed similar discipline-based views, the data also confirmed that there were teachers in the Hard/Pure disciplines who draw on literature on learning and teaching, even if less disposed to investigate the same phenomena. The caricature of disciplines needs to be avoided. Healey (2008) echoes this warning when observing that there is the potential for disciplines to become silos because their members ignore other disciplinary perspectives and avoid interdisciplinary encounters. And, Huber and Morreale (2002) have observed, "Growth in knowledge also comes at the borders of disciplinary imagination ... It is in this borderland that scholars from different disciplinary cultures come to trade their wares - insights, idea and findings - even though the meanings and methods behind them may vary considerably among producer groups" (p. 1). There have also been calls for a broader focus for SoTL work. Kreber (2007) advocates an agenda for SoTL that goes beyond discipline-specific inquiries into how students learn and accommodates questions relating to the larger learning experience of students. Similarly, Huber and Hutchings (2005) identify a number of contexts in addition to discipline that could be taken into account.

The work of teaching occurs in an almost infinite set of contexts - contexts defined by discipline, student demographics, institutional type, pedagogical approach, and curricular goals, to name just a few of the elements whose permutations distinguish one classroom from another. (p. 35)

Most recently, Boshier and Huang (2008) contend that "The ' $\mathrm{L}$ ' part of SoTL is stalled because advocates are too focussed on classrooms in institutions... SoTL advocates need to get out of the office, descend from the hills and examine learning in natural settings" (p. 647).

Another factor that appeared to influence involvement in SoTL was conception of teaching. 58\% of the 124 AUT teachers reported that they held a student-centred conception of teaching. One-third reported a teacher-focussed orientation and the balance considered both orientations were represented in their teaching. An orientation towards a student, rather than teacher, centred conception of teaching was more evident in teachers engaged in SoTL investigations (45\% vs. 29\%). This data coincides with findings from an exploratory study by Lueddeke (2003) and a longitudinal study of teachers over two years which indicated that teachers who had, or acquired, student-focussed conceptions were more likely to demonstrate features of scholarly teaching (McKenzie, 2007). It also reinforces the view that facilitating a shift towards a student-focussed orientation may engender perspectives conducive to engagement in SoTL

\section{Incentives and barriers}

Four conditions featured most prominently in those respondents indicated would increase the likelihood of their engagement in SoTL activities: more time; more professional development opportunities related to SoTL; more collegial interaction and support associated with engagement in SoTL; and a culture shift that, as one teacher stated, would be reflected in "a widespread emphasis on the necessity for tertiary educators to also be researchers of their educational practices and even 
further, publishers of educational research in their discipline." A wide range of other specific personal and contextual factors were perceived as representing necessary preconditions for engagement in SoTL activities or as associated 'pull', 'drag' or 'push' factors (Figure 2).

Figure 2: Factors that influence individual participation in SoTL

\section{Personal conditions pre-requisite for SoTL engagement}

- Whether overall and/or academic demands and priorities in teacher's life allow space for engaging in SoTL.

- Personal interest in investigating an aspect of teaching-learning, stemming from teaching experiences.

- Personal perception of agency in relation to teaching.

- General confidence in research capabilities.

- SoTL research confidence.

- Sense of comfort / capability re teaching, but readiness to move on, taking conditional steps.

2. Pull factors - External Enablers

- Other's expectation of evidence to support teaching decisions and/or to confirm teaching effectiveness.

3. Drag factors (External) - Obstacles

Internal

- Absence of personal pre-conditions (as above).

- View that personal research will not interest a wider audience.

- Reticence in putting SoTL-based ideas in to the public domain.

- Getting SoTL activities off the ground - overcoming own and others' inertia.

- Work overload, leading to shutdown on 'extras'.

- Conflicting priorities (teaching, administration, other professional development).

- Need to give priority to staying up to date with rapidly changing subject/discipline area knowledge.

- Negative experiences / perceptions of ethics requirements for SoTL projects.

\section{$\underline{\text { External }}$}

- Low(er) value/priority accorded teaching compared with research - which may be exacerbated by the New Zealand Performance Based Research Fund (PBRF) regime.

- Absence of a culture and/or history of enquiry into teaching.

- Limited funding for SoTL activities.

- Publication delays which inhibit desire to work towards publication.

- Perceived limited quality, relevance and utility of SoTL literature. 
- Demands of proposal writing.

- Complexity of ethics application process, delays.

4. Push factors (External) - Obstacles

- Further avenue for meeting PBRF expectations.

- Option for fulfilling personal postgraduate research expectations.

While many of these factors have been identified in other investigations (Lynch et al., 2002; CEBE, 2004; Sample, 2004; Oakley et al., 2005; Dobbins, 2008) for each respondent, they clearly played out in both complex and idiosyncratic ways to determine the extent and nature of their engagement in SoTL. AUT University respondents also identified a range of factors specific to their context that represented helps or hindrances to their engagement in SoTL and proposed initiatives in turn that were clearly associated with those factors. Overall, the data conveys a sense of the complex and often conflicting everyday environments that university teachers work in and that can make pursuit of SoTL problematic. It also foreshadows initiatives that could pull and push teachers towards SoTL and enable their movement along the 'excellent teacher' to 'scholarly teacher' to 'scholar of teaching' continuum. Again, those initiatives would need to be aligned with the distinctive features of teachers' contexts.

\section{Goals for engagement in SoTL}

The data indicated that $34 \%$ of the AUT teachers hoped to have made positive movement, in 2 to 5 years time, along the continuum of SoTL engagement. However, for approximately half of the respondents, no change was contemplated and regression of degree of involvement was foreshadowed by the balance of respondents (17/114). The aspiration to move beyond personal investigations of learning and teaching to communication of insights to colleagues who might in turn subject them to peer review was infrequently identified (2/114 respondents).

While we may hope that movement along the route of excellent teacher - scholarly teacher - scholar of teaching will be always be uni-directional and constant, this is understandably, not the case. All teachers on occasions find themselves back in the status of a novice reliant on getting started rules provided by a colleague. As Waering (1999) has observed, it is also "possible for teaching skills to go backward temporarily while scholarship goes forward: people ... [may] get self-conscious and confused as their knowledge increases, and take a while to digest new learning and put it usefully into practice" (as cited in Healey, 2000, p. 175). Benson (2001) conceded that

In my own attempts at the scholarship of teaching, not all of the ideas and things I have tried resulted in increased student learning. Many have had an effect, others have had no effect, and some event resulted in less student learning. (p. 2)

We also believe that while all teachers should become scholarly, no 'target' is reasonable or realistic for the emergence of scholars of teaching. This stance does not preclude our view that the more the better. 


\section{Evaluating the impact of SoTL}

Surprisingly, there is limited literature that addresses the issue of impact criteria. A helpful recent contribution has been made by Ciccone (2008) who reviews 10 "areas of impact" that members of the Carnegie Foundation for the Advancement of Teaching have identified. The areas include contribution to important agendas and initiatives in higher education, change in how teachers teach and their knowledge about factors that make change happen, change in how we understand and talk about teaching, direct and indirect effects on student learning, contribution to knowledge of the conditions that effect exchange and improvement of pedagogy, strengthen development programmes for higher education professionals, inform changes in the policies and procedures of the institution, affect the culture of academic life, change how we define and evaluate scholarship, and growth and evolvement of the SoTl movement.

Our view is that while such a broad array of indicators is appropriate, impact on student learning must be the primary indicator. This stance is endorsed by Trigwell and Shale (2004) who contend that "Ultimately, it is that experience (students' experiences of university learning) that a good conception of scholarship of teaching must, in our view, serve to enhance. (p. 524)

However, major methodological challenges must be acknowledged and addressed when the relationship between engagement in SoTL and student learning is investigated. Those challenges arise from the inherent complexity of social phenomena, including those involving scholarship/research, learning and teaching (Davis \& Sumara, 2005). Those challenges may contribute to limited extensive impact that SoTL findings are frequently perceived to have had on the practice of teachers, other than the individual scholar/practitioner (Coolbear et al., 2009).

In one recent attempt to address those challenges Brew and Ginns (2008) developed a Scholarship of Teaching index which consists of a set of questions which are responded to by members of an academic department. The questions focus on teacher preparation (e.g., participation in a postgraduate tertiary teaching programme, the application of educational research), teaching awards and publications and presentations on teaching and learning). Scores are aggregated and correlated with measures of students' perception of the learning experience. In turn, the aggregated scores become the basis for an allocation of funding to departments that takes into account staff contributions to teaching quality through their engagement in SoTL. Evidence accumulated from use of this measure has also been offered to substantiate a relationship between engagement in SoTL and better student learning experiences as assessed using the Student Course Experience Questionnaire (SCEQ). A further exemplar is an investigation of the relationship between academic development that embodied a SoTL-related agenda and student learning (Haigh \& Naidoo, 2007).

\section{Conclusion}

The rationale and agenda for this project is reflected in Shulman's (2000) thoughtful views about what he suggested might be called the "new research universities": "institutions of higher education that take both teaching and inquiry into teaching seriously"; "an institution that takes its work so seriously that it makes that work the most important focus of its own investigations" (p. 105). 
In this instance, we sought to realize that aspiration by basing our decisions about future work intended to encourage and support our colleagues' engagement in SoTL on the outcomes of a scholarly investigation into the current presence of SoTL within our institutions and the day to day work life of our colleagues. While we certainly see ways in which the methodological integrity of our investigation could be improved, the impact of the findings is already significant. As intended, they have informed our decisions about future initiatives to encourage and support SoTL. For example, we are currently prompting institution-wide discussion about the meaning and import of our university's commitment to 'research-led teaching', contributing to an on-going review of the PBRF scheme in relation to the status of SoTL and pedagogical research, and addressing one of the specific obstacles that a number of colleagues associate with SoTL investigation (obtaining ethics approval for projects). As we implement such initiatives, we will re-deploy some of the stock-taking frameworks and processes outlined above to assess their impact. We will also seek to improve those methods, drawing on the parallel work of other members of the SoTL community (e.g., McKinney, 2009).

\section{References}

Becher, T. (1994). The significance of disciplinary differences. Studies in Higher Education, 19(2), 151-161.

Benson, S. (2001). Defining the Scholarship of Teaching and Learning in Microbiology. Retrieved 16 August, 2008, from http://www.cte.umd.edu/staff/spencer/SbensonSoTL-FOME.pdf

Boshier, R. (2009). Why is the scholarship of teaching and learning such a hard sell? Higher Education and Research, 28(1), 1-15.

Boshier, R., \& Huang, Y. (2008). In the house of Scholarship of Teaching and Learning (SoTL): Teaching lives upstairs and learning in the basement. Teaching in Higher Education, 13(6), 645-656.

Brew, A., \& Ginns, P. (2008). The relationship between engagement in the scholarship of teaching and learning and students' course experiences. Assessment \& Evaluation in Higher Education, 33(5), 535-545.

Centre for Education in the Build Environment (2004). Education research in planning: Why publish educational research? A paper of the Educational Research in Planning Special Interest Group. Retrieved on 6 May, 2005 from http://www.cbe.heacademy.ac.uk/learning/sig/education/trigger_why.php

Ciccone, T. (2007). Systematic inquiry: From classroom practice to institutional strategy. The International Commons, 2(2), 8-9.

Ciccone, T. (2008). Examining the impact of SoTL. The International Commons. 3(1), 12-13. Available at http://www.issotl.org/International_Commons_3_1.pdf

Coolbear, P., Weir, K., \& Sellers, P. (2009, April). From fragmentation to cooperation: Examining the state of and progress towards a unified approach to educational research in New Zealand. Paper presented at the Bightstar Tertiary Education Summit, Wellington, New Zealand. Retrieved from http://www.brightstar.co.nz/nz/conference_presentations/conference_presentations/B C002/Peter-Coolbear-paper-16.04.09.pdf

Coppola, B., \& Jacobs, D. (2002). Is the scholarship of teaching and learning new to chemistry. In M, Huber and S. Morreale, (Eds.), Disciplinary styles in the Scholarship of Teaching and Learning: A Conversation (pp. 197-216). Washington: American Association of Higher education/Carnegie Foundation for the Advancement of Teaching. 
Davis, B. and Sumara, D. (2005). Challenging images of knowing: Complexity science and educational research. International Journal of Qualitative Studies in Education, 18(3), 305-321.

De Welde, K., \& Seymour, E. (2008, 31 July). Resistance is sustaining pedagogical Innovations: Lessons for sociology from STEM Innovators. Paper presented at the Annual Meeting of the American Sociological Association, Boston, MA. http://www.allacademic.com/meta/p241205_index.html

Dobbins, K. (2008). Enhancing the Scholarship of Teaching and Learning: A study of the factors identified as promoting and hindering the scholarly activities of academics in one faculty. International Journal for the Scholarship of Teaching and Learning, 2(2).

Dreyfus, H., \& Dreyfus, S. (1986) Mind over machine: The power of human invention and expertise in the era of the computer. New York: Free Press.

Education Ammendment Act (1990). Section 162(4)(a), Clause (ii), p. 33.

Gayle, B. M., \& Randall, N. (2007). Faculty learning through SoTL faculty development: Impact on student learning. Paper presented at the Annual Conference of the International Society for the Scholarship of Teaching and Learning, Sydney.

Gossman, P. (2008) Teaching development - experience and philosophy (using the three Rs). Teacher Education Quarterly, 35(2), 155-169

Gossman, P., Haigh, N., \& Jiao, X. (2009). The status of the Scholarship of Teaching and Learning (SoTL) in New Zealand Universities: Three institutional case studies. Auckland, New Zealand: AUT University.

Gurung, R., Ansburg, P., Alexander, P., Lawrence, N., \& Johnson, D. (2008). The state of the scholarship of teaching and learning in psychology. Teaching of psychology, 35, 249261.

Haigh, N. (2006). Tertiary Teacher Development and Ako Aotearoa: The National Centre for Tertiary Teaching Excellence. New Zealand Journal of Teachers' Work, 3(2), 108114.

Haigh, N., \& Naidoo, K. (2007, 11-13 December). Engaging in the scholarship of academic development practice: facing a challenging agenda. Paper presented at the Society for Research into Higher Education (SRHE) Annual Conference Brighton, Sussex.

Haigh, N., \& Stein, S. (2006). Submission on behalf of the New Zealand Branch of the Higher education Research and Development Association of Australasia to the consultation on the Second Tertiary Strategy.

Healey, M. (2000). Developing the Scholarship of teaching in higher education: A disciplinebased approach. Higher Education Research and Development, 19(2), 169-189.

Healey, M. (2003). The scholarship of teaching: issues around an evolving concept. Journal on Excellence in College Teaching, 14(2/3), 5-26.

Healey, M. (2008). On discipline-based approaches to SoTL. The International Commons, 3(1), 2, available at http://www.issotl.org/international_commons_3_1.pdf.

Huber, M. T., \& Morreale, S. P. (Eds.). (2002). Disciplinary styles in the scholarship of teaching and learning: exploring common ground. Washington, DC: American Association for Higher Education.

Huber, M., \& Hutchings, P. (2005). The advancement of Learning: Building the teaching Commons. San Francisco: Jossey-Bass.

Hutchings, P., \& Huber, M. (2008). Placing theory in the scholarship of teaching. Arts and Humanities in Higher education, 7(3), 229-244.

Kreber, C. (2002a). Controversy and Consensus on the scholarship of teaching. Studies in Higher Education, 27(2), 151-167.

Kreber, C. (2002b). Teaching excellence, teaching expertise, and the scholarship of teaching. Innovative Higher Education, 27(1), 5-23. 
Kreber, C. (2003). The scholarship of teaching: Conceptualizations of experts and regular academic staff. Higher Education, 46(1), 93-121.

Kreber, C. (2005). Charting a critical course on the scholarship of university teaching movement. Studies in Higher Education, 30(4), 389-405.

Kreber, C. (2007). The scholarship of teaching and learning: No one way. Interchange (Newsletter of the centre for Teaching, Learning and Assessment. University of Edinburgh).

Lueddeke, G. (2003). Professionalizing teaching practice in higher education: A study of disciplinary variation and 'teaching-scholarship'. Studies in Higher Education, 28(2), 213-228.

Lynch, J., Sheard, J., Carbone, A., \& Collins, F. (2002). The scholarship of teaching: risky business in ICT education. Retrieved on 5 March 2007 from http://www.aare.edu.au/02pap/lyn02030.htm

Martin, E., Benjamin, J., Prosser, M., \& Trigwell, K. (1998). Scholarship of teaching: A study of the approaches of academic staff. Paper presented at the 6th Improving Student Learning Symposium, Brighton, UK.

McKenzie, J. (2007). Variation in patterns of teacher development and change: connections with the development of scholarly teaching and the scholarship of teaching. Paper presented at the Annual Conference of the Higher Education Research and Development Society of Australia, Adelaide.

McKinney, K. (2004). The scholarship of teaching and learning: Past lessons, current challenges, and future visions. To Improve the Academy, 22, 3-19.

McKinney, K. (2007). What are disciplinary and institutional contexts of SoTL. In K. McKinney [Eds.], Enhancing learning and teaching through the scholarship of teaching and learning (pp. 101-118). San Francisco: Jossey Bass/Anker.

McKinney, K and Jarvis, P. (2009). Beyond lines on the CV: Faculty applications of their scholarship of teaching and learning research. International Journal for the Scholarship of Teaching and Learning, 3(1).

Ministry of Education. (2005). The Statement of Education Priorities 2005 -2007. Retrieved. from http://www.tec.govt.nz/upload/downloads/step05-07.pdf.

Education, M. o. (2007). Tertiary Education Strategy. Retrieved. from http://www.minedu.govt.nz/ /media/MinEdu/Files/EducationSectors/TertiaryEducati on/TertiaryEducationStrategy.pdf.

Nicholls, G. (2005). New lecturers' constructions of learning, teaching and research in higher education. Studies in Higher Education, 30(5), 611-625.

Oakey, D., Coates, N., \& Roberts, C. (2004, September 13-14). Salford and the Scholarship of Teaching and Learning: Perspectives and participation across the disciplines. Paper presented at the Education in a Changing Environment Conference, the University of Salford, Greater Manchester, UK. Retrieved on 6 September, 2007 from http://www.edu.salford.ac.uk/her/

Prosser, M. (2008). The scholarship of teaching and learning: What is it? A personal view. International Journal for the Scholarship of Teaching and Learning, 2(2).

Richlin, L. and Cox, M. (2004). Developing scholarly teaching and the scholarship of teaching and learning through faculty learning communities. New Directions for Teaching and Learning, 97, 127-135.

Sample, M. (2004). The VKP@3 Faculty Survey. Visible Knowledge project. Retrieved from http://cndls.georgetown.edu/crossroads/vkp/newsletter/0304/issues.htm on 6 May, 2005

Shulman, L. (2000). Inventing the future. In P. Hutchings (Eds.), Opening lines: Approaches to the scholarship of teaching and learning (pp. 95-105). Menlo Park, CA: The Carnegie Foundation for the Advancement of Teaching. 
Smith, R. (2001). Expertise and the scholarship of teaching. In C. Kreber (Eds.) Scholarship revisited: Perspectives on the Scholarship of Teaching (pp. 69-79). San Francisco: Jossey Bass

Trigwell, K. and Shale, S. (2004). Student learning and the scholarship of university teaching. Studies in Higher Education, 29(4), 523-536.

Wankat, P., Felder, R., Smith, K. and Oreovic, F. (2002). The scholarship of teaching and learning in engineering. In M, Huber and S. Morreale, (Eds.) Disciplinary styles in the Scholarship of Teaching and Learning: A Conversation (pp. 217-237). Washington: American Association of Higher Education/Carnegie Foundation for the Advancement of Teaching.

\section{[6,938 words]}

